\title{
Empowering the South African community's AIDS intervention workforce: an informetric study of HIV/AIDS research projects, with special reference to masters and doctoral dissertations and theses
}

\author{
By Omwoyo Bosire Onyancha' \\ Department of Library and Information Science \\ University of Zululand, Private Bag X100I, KwaDlangezwa 3886 South Africa \\ b_Onyancha@yahoo.com
}

\begin{abstract}
Received $14^{\text {th }}$ January 2006
Accepted I ${ }^{\text {st }}$ February 2006

The prevalence rate of HIV in South Africa has maintained an alarmingly high level and has become a great concern for all stakeholders. The situation has demanded an increase in the number and strengthening of the HIV/AIDS intervention workforce to fight the pandemic. This has resulted in many individuals enrolling to undergo training in institutions of higher learning and the aftermath has been an increased number of graduates conducting research on various aspects of the disease. The purpose of this study is to generally assess the role that is being played by various institutions of higher leaning in South Africa in graduate preparedness as a means of empowering the country's HIVIAIDS intervention workforce. Using publication count, the study analyses research publications found indexed in SABINET's Current and Completed Research and the Union Catalog of Theses and Dissertations databases. Results are presented under the headings: empowerment trends; language of empowerment; institutions behind the empowerment; individuals behind the empowerment: "study leaders" and students; information sources for empowerment; purposes for which candidates were prepared (or empowered); and the areas/sectors of empowerment. Conclusions and recommendations as well as suggestions for further research are provided.
\end{abstract}

Keywords: HIV, Acquired Immunodeficiency Syndrome, Informetrics, South Africa, Empowerment

\section{INTRODUCTION}

In the business circles, the term empowerment refers to a condition whereby employees have the authority to make decisions and take action in their work places without prior approval (www.asq.org/info/glossary/e.html) while to empower a community means to increase its ability to do things for itself, resulting to more skills, more confidence, and more effective organization on the part of the empowered community. Health professionals, on the other hand, define empowerment as a process of adding vitality, energy, and new powerful resources to a person (www.neurosemantics.com/ Articles/Glossary.htm). When these three definitions are put together, empowering a community and its labor force will mean enabling it to do things for itself through the allocation of financial resources, training of professionals in various fields of knowledge as well as the provision of relevant information that can aid in informed decision-making thereby enhancing a community's vitality, energy and human resources.

Worldwide, universities are recognized for their role in human resources development. Countries all over the world do recognize the importance and role of universities and other institutions of higher learning such as diploma and certificate colleges in the promotion of research, training and community outreach and, in the process, have put in place mechanisms to improve research in various disciplines, including biomedicine. Policies have been formulated in countries such as South Africa in order to encourage as well as strengthen research in such areas as HIV/AIDS. For instance, in South Africa, the Ministry of Education - the government arm that is mandated to lead the education sector's strategic response to HIV/AIDS and to continually refine the response on the basis of emerging evidence, among other responsibilities - is required to:

- Develop appropriate policies and legislative frameworks to respond to HIV/AIDS across all levels of the system.

- Provide the required technical input into the planning for the Education system in the context of HIV/AIDS, at National and Provincial levels.

- Facilitate research and collection of Education-specific data on HIV/AIDS in order to inform Departmental responses.

- Coordinate the Department's collaborative activities across other Government Departments and all sub sectors.

- Communicate the Education Response to the public and lead the Education Campaign against HIV/AIDS.

- Monitor the implementation of the HIV/AIDS program and feed lessons into re-programming (Republic of South Africa. Ministry of Education, 2005)

I. The writer is a PhD student at the University of Zululand and an Assistant Librarian at the University of Eastern Africa, Baraton, P.O. Box 2500, ELDORET - KENYA. 
Generally, it can be assumed that South Africa boasts one of the largest and well-developed education networks, especially in tertiary education, in Sub-Saharan Africa. The country, which is internationally highly rated in terms of research productivity and impact in relation to other African countries (Ocholla, 2000; He, 200I; Narvaez-Berthelemot, Russell, Waast \& Gaillard, 200I), has 21 higher education institutions, consisting of II universities, 6 technikons (now Universities/Institutions of Technology) and 4 comprehensive institutions (Republic of South Africa, Ministry of Education, 2002).

Concerning HIV/AIDS intervention programs, it has been observed that institutions of higher learning in South Africa have designed programs to effectively respond to the "challenges of the disease by incorporating HIV/AIDS into the curriculum ... to promote more flexible graduate preparedness" (Dube \& Ocholla, 2005:198). In so doing, these institutions continually inject "new blood" into the South African community of workers, thereby, adding "vitality" and "energy" into the entire community in the fight against HIV/AIDS. Hence, the thrust of this work lies in examining how these and other institutions in South Africa have helped to reinforce the South African HIV/AIDS workforce and the entire citizenry, particularly in the preparation of graduate students.

\section{BACKGROUND AND PROBLEM STATEMENT}

It is approximately 25 years since HIV/AIDS was clinically diagnosed in Los Angeles, USA (Begley, Check, Wingert \& Conway, 200I; Konforti, 200I; National Institute of Allergy and Infectious Diseases [NIAID], 2003). Since then, the disease has devastatingly spread to all corners of the world killing millions of people while leaving many children orphans and nowhere is its impact most felt as in southern Africa. HIV prevalence has continued to maintain alarmingly high levels in the general population across southern Africa (UNAIDS, 2003). UNAIDS further estimates that about $30 \%$ of people living with HIVIAIDS worldwide live in southern Africa, yet this region has less than $2 \%$ of the world's population. Currently, South Africa is ranked the fifth in the top 15 HIV prevalence countries in Africa (UNAIDS, 2004) with a prevalence rate of $21.5 \%$ behind Swaziland (38.8\%), Botswana (37.3\%), Lesotho (28.9\%), and Zimbabwe (24.6\%). In fact, it has one of the fastest-growing infection rates in the world (MacGregor 200 I, UNAIDS 2000, \& UNESCO 2003 in Dube \& Ocholla, 2005).

It is projected that by the end of this year (i.e. 2005), almost 250000 South Africans would have died from AIDS and that this figure will rise to half a million people by 2008 while the average life expectance is expected to fall from about 60 years to around 40 years between 1998 and 2008 (AIDS Foundation of South Africa, 2003). Impact-wise, the Foundation observes that within that time frame, HIV/AIDS will pose significant economic costs, slowing the economic growth (Gross Domestic Product - GDP) rate by $1 \%$ per annum; HIV/AIDS care will become a substantial part of health care spending; education will be affected by the staff becoming infected; social and political instability will increase; and the pandemic will produce large numbers of orphaned children (approximately a million children under 15 years by the end of 2005).

HIV/AIDS research has proliferated in the recent past and in the process, has attracted several researchers with no particular bias to any discipline. Evaluating and monitoring HIV/AIDS research, therefore, becomes a top priority especially considering that institutions have continued to spend so much money in funding these research activities. The Developed Countries (DCs) have made a great deal of developmental strides in that direction unlike Less Developed Countries (LDCs). For instance, several evaluative studies, using informetric approaches, have been conducted in the DCs in order to find out the most prolific researchers in HIV/AIDS (The Scientist, 1996), the growth of literature (Pratt, 1992; Mackenzie, 2000; Huber, Gillaspy \& Fogel, 2000), and the publishing trend in the subject sub-fields (Bierbaum, 1995), just to mention a few. The LDCs are lagging behind as far as these evaluative studies are concerned with very little research being conducted, e.g. Latin America (Macias-Chapula, 2000; Macias-Chapula, Sotolongo-Aguilar \& SolorioLagunas, 1999) and Sub-Saharan Africa, e.g. Central Africa (Macias-Chapula, C. A. \& Mijangos-Nolasco, A. 2002) and Kenya and Uganda (Onyancha \& Ocholla, 2004). These studies' focus, however, has been on HIV/AIDS research as it is published in books, conference proceedings, and journal articles. So far, according to own knowledge, no informetric study has been carried out on unpublished sources of HIV/AIDS information, using data from dissertations and theses, in Sub-Saharan Africa. However, an analysis of these sources of information was conducted by Ocholla (2000) with the aim of providing an awareness of the overall research potential and capacity in Library and Information Science in South Africa and, particularly, the potential of institutions in the country. The study was broad and did not address HIV/AIDS in particular.

\section{PURPOSE AND RESEARCH QUESTIONS}

The purpose of this work is two-fold:

I. The study presents preliminary findings of an informetric analysis of HIV/AIDS literature in eastern and southern Africa as reflected and indexed in renowned bibliographic databases. 
2. The study also seeks to demonstrate the use of informetrics in evaluating HIV/AIDS research intervention programs at institutions of higher learning. In its audit of the HIV/AIDS intervention programs in the South African institutions of higher learning, the South African Universities Vice-Chancellors Association noted that, “... the audit was unable to obtain detailed, quantitative information because of time constraints and limited availability of information from the institutions' heads of research. Moreover, the audit demonstrates that research outputs are difficult to track because of large number of departments in each HEl, and research may also be linked to contract services supplied by units based at HEls that are not linked to teaching" (The South African Universities Vice-Chancellors Association, Higher Education HIV/AIDS Programme, 2004:xii).

Specifically, this work analyzes HIV/AIDS research reflected in masters and doctoral theses and dissertations as well as other research publications in South African institutions in order to study how the universities, in particular, and other institutions, in general, in South Africa have helped to empower the South African community's HIV/AIDS workforce in the AIDS war. The study endeavors to identify the following: empowerment trends; language(s) of empowerment; institutions behind the empowerment; individuals behind the empowerment: "study leaders" and students; information sources for empowerment; purposes for which candidates were prepared (or empowered); and areas/sectors of empowerment.

\section{METHODS AND MATERIALS}

Informetrics is defined in Diodato (1994:ix) as methodologies that examine "patterns that show up not only in publications but also in many aspects of life, as long as the patterns deal with information". Hood \& Wilson (2001:294) observe that the term "comes from the German term 'informetrie' and was first proposed in 1979 by Nacke to cover that part of information science dealing with the measurement of information phenomena and the application of mathematical methods to the discipline's problems, to bibliometrics and parts of information retrieval theory, and perhaps more widely". The importance of bibliometrics/informetrics methods as tools for evaluating scientific impact is well stipulated by Moed (2002:731), thus:

Bibliometric/[informetric] indicators provide useful supplementary tools in the evaluation of academic research, provided that they have a sufficiently high level of sophistication... Their application can stimulate useful discussion among scientists and research managers about publication strategies and research directions; help peer-reviewers to make quality judgments; and enable policy officials and science administrators to raise critical questions about many aspects of scientific activity and to provide insight for policy (funding) decisions.

Informetrics consists of several methodologies such as bibliographic coupling, citation analysis, publication count, coword analysis, co-citation analysis and webometrics/cybermetrics (Turnbull, 2000); Ungern-Sternberg, 1995; UngernSternberg, 2000). These evaluative/analytical techniques can be grouped into two broad areas, namely, descriptive or evaluative informetric research methodologies (Nicholas \& Ritchie, 1978; Hertzel, 1987). Descriptive studies (sometimes called productivity count studies) describe "the characteristics or features of a literature" while evaluative studies (called behavioral studies or sometimes known as citation studies, though not necessarily restricted to these) "examine the relationship formed between components of a literature" (Nicholas \& Ritchie, 1978:10). Considering the type of data collected, this study adopted the use of publication count and analysis approach to examine research productivity in institutions of higher learning in South Africa as reflected in two South African Bibliographic Network (SABINET) databases.

The Current and Completed Research (C\&CR) database contains South African research projects covering the social sciences, humanities, economic and management sciences. The database includes masters and doctoral theses of South African universities, and technikons as well as information on research projects from non-governmental organizations, private sector and government departments. The database, which is updated monthly, covers research projects undertaken since 1950. On the other hand the Union Catalog of Theses and Dissertations (UCTD) - updated annually is produced by the North-West University (formerly Potchefstroom University for Higher Education) and contains bibliographic records of theses and dissertations at master and doctorate level submitted to universities in South Africa since 1918. Honorary doctorates are also included.

A combination of several search terms/phrases (i.e. AIDS, ACQUIRED IMMUNODEFICIENCY SYNDROME, ACQUIRED IMMUNE DEFICIENCY SYNDROME, ACQUIRED IMMUNO-DEFICIENCY SYNDROME, HUMAN IMMUNODEFICIENCY VIRUS, HUMAN IMMUNE DEFICIENCY VIRUS, and HIV) was used to search for relevant records within the "Keywords" and "Subject" fields, accordingly. The retrieved records were then saved in HTML format. The records were thereafter cleaned of any duplicates and edited using Microsoft Word (C2000). Bibexcel, a toolbox that was developed by Olle Persson of Inforsk, Umeå University, Sweden, was used to generate frequencies. Basically, the software is designed to assist a user in analyzing bibliographic data, or any data of a textual nature formatted in a similar manner. It is meant to generate data files that can be imported to Excel, or any program that takes tabbed data 
records, for further processing. The toolbox can be downloaded from http://www.umu.se/inforsk/Bibexcel/. Finally, data was exported to Microsoft Excel (@2000), which assisted in the cleaning of data by removing HTML (mark-up) tags and the presentation of data in graphs and tables.

A total of 105 records in the Union Catalog of Theses and Dissertations (UCTD) and 895 research projects from the Current and Completed Research (C\&CR) were retrieved and downloaded. After the cleaning and editing of the downloaded data, a total of 902 records were obtained and analyzed as shown in Fig. I.

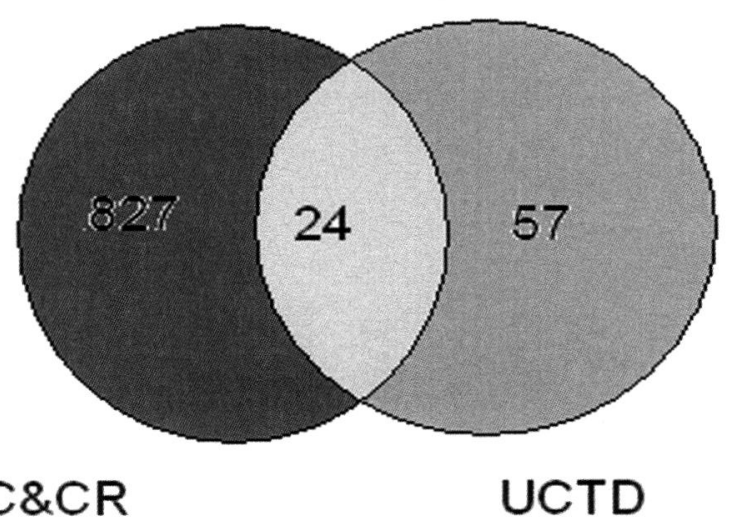

Figure 1 Total number of records retrieved for analysis distributed by database

Of the total 902 records analyzed, C\&CR yielded $85 \mathrm{I}$ and UCTD produced $5 \mathrm{I}$. Twenty four titles were indexed in both databases. There were 827 and 57 unique records indexed in C\&CR and UCTD, respectively. Coverage overlap was 24 unique items resulting in coverage overlap ratio of 0.03 .

Using descriptive informetrics, the study employed several analytical approaches to analyze and present the downloaded data. These approaches include:

I. A distribution of records by the institutions in order to determine the institutions behind the empowerment of the South African AIDS workforce and the most prolific of these institutions.

2. A distribution of the records by the participating "study leaders" so as to identify and measure the productivity of individuals behind the preparation of the graduates.

3. An analysis of the trend of productivity by year of commencement, completion and publication of the research projects in order to study the empowerment trends.

4. A study of the language of publication in order to identify the most commonly used language of communicating research findings as well as the most commonly used language of empowerment.

5. An assessment of the main subject headings in order to check for interdisciplinary approaches to HIV/AIDS research.

6. An analysis of the academic purpose and professional attainment so as to identify the sectors that are being empowered and the professionalism of the candidates.

7. A study of the document types in order to examine the sources of information for empowerment.

\section{RESULTS AND DISCUSSION}

Results are presented in seven sub-headings as follows:

- Empowerment trends

- Language of empowerment

- Institutions behind the empowerment

- Individuals behind the empowerment: "study leaders" and students

- Information sources for empowerment

- Purposes for which candidates were prepared (or empowered)

- Areas/sectors of empowerment 


\subsection{Empowerment trends}

In order to find out the trend of HIV/AIDS research and, consequently, the empowerment trends of the South African community, data were analyzed by the years that the research projects were began, completed and published. Of particular emphasis, though, were the dates the projects were completed as this would indicate the years in which the candidates graduated which in turn will indicate the period in which the community's workforce was re-energized. This approach to analysis and argument assumes that whether the graduates were employed or not upon the completion of their academic programs/projects, they nevertheless became HIV/AIDS intervention instruments in the community.

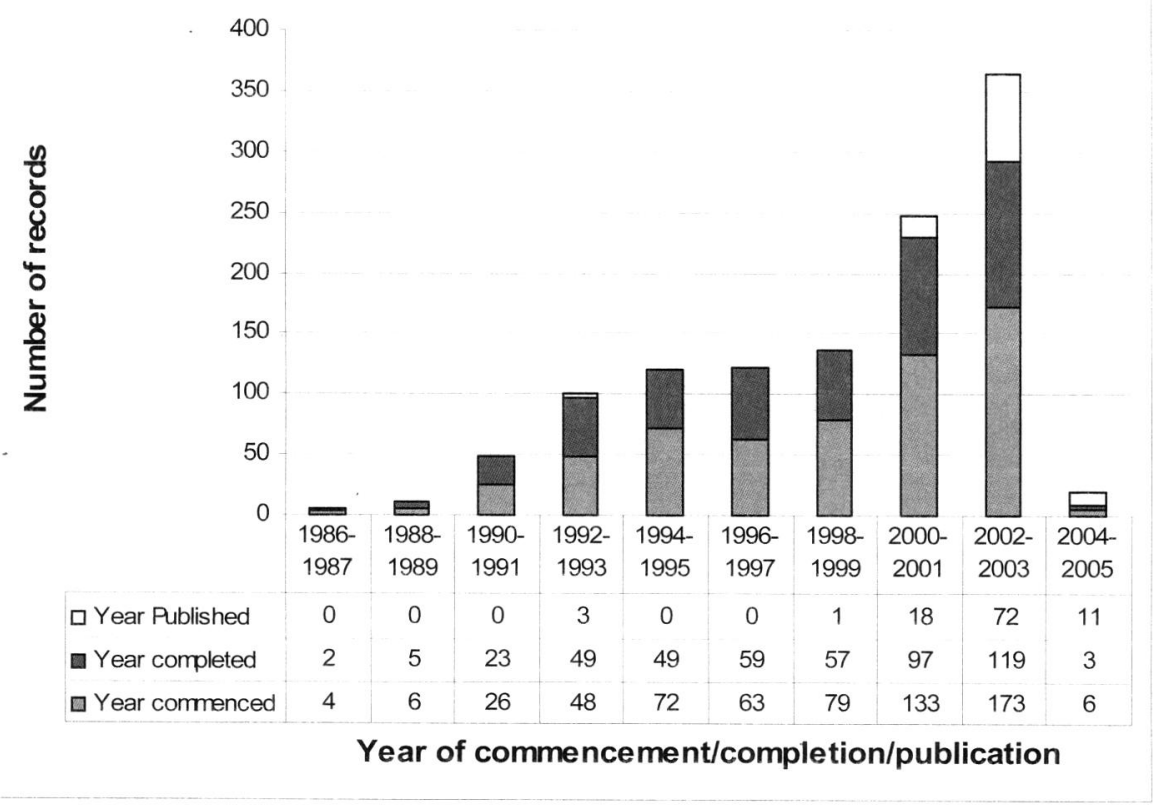

Figure 2 Total number of records by year of commencement, completion and publication

Results in Fig. 2 indicate that 219 projects were completed between 2000 and 2005 while the same period recorded 312 commenced projects. The 1990s yielded 237 and 238 completed and commenced projects, respectively and there were only 7 completed and 10 registered projects between 1980-1989. It can be seen that much of the research activities were centered around 2000 and 2003, which period recorded the highest number of current, ongoing and completed projects. The number of research projects that were published before that period totaled 4 while 2000-2003 year-period recorded a total of $\mathrm{IOI}$ publications.

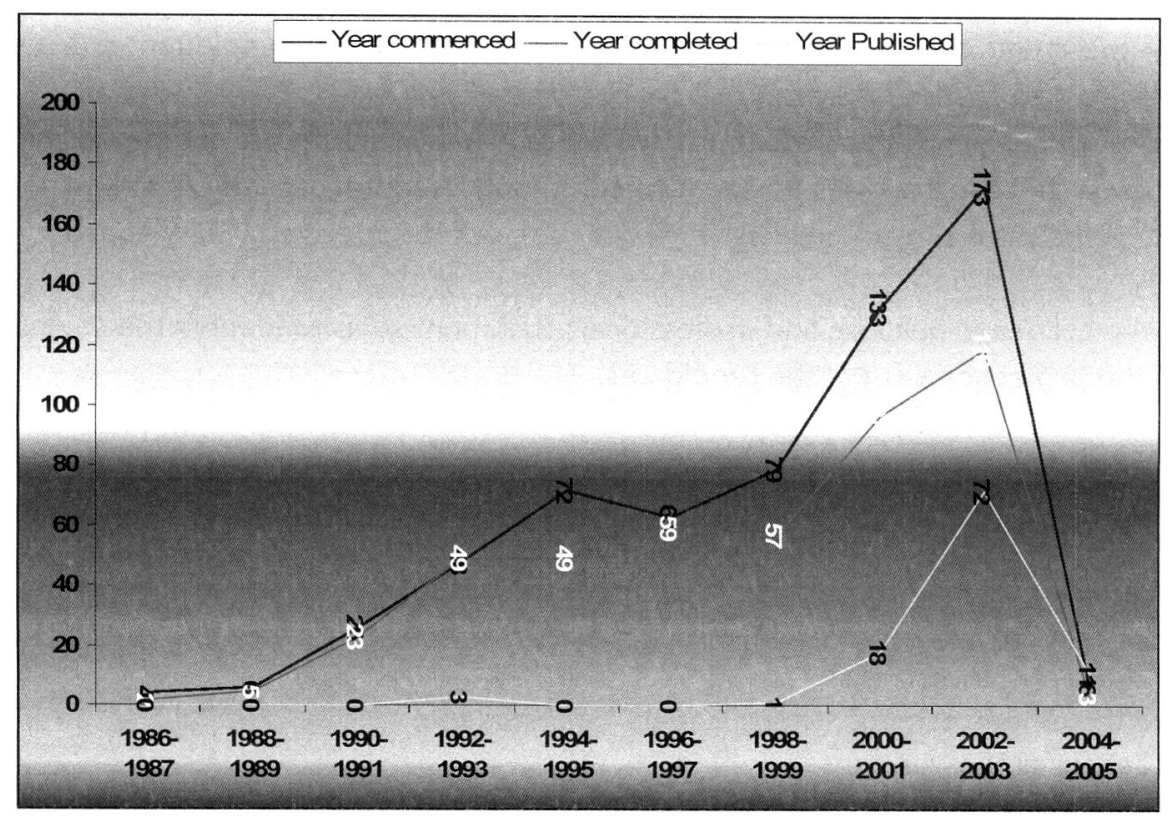

Figure 3 Trends of productivity/empowerment 
Fig 3 shows that the frequency with which the projects are being registered for commencement is always higher than that of completion and publication. It was also observed that the earliest projects to be conducted were two Masters Projects. Both were completed between 1986 and 1987 (one in each year). Assuming that the two projects that were completed by 1986 or 1987 were started two years backwards, it means that HIV/AIDS research in institutions of higher learning in South Africa began in the early eighties, i.e. 1984/5 or thereby. The time lapse between the diagnosis of the disease in $198 \mathrm{I}$ and the commencement of research on HIV/AIDS (i.e. 1984/5) was three to four years, which may have been caused by the traditional inhibitions and taboos that made many African people rarely discuss sexuality and more so about AIDS, at least openly. In their study of Newspaper coverage of SARS, Chan, Jin, Rousseau, Vaughan \& Yu (2003) also opine that "it is just human that the meaning of new phenomena is not immediately clear, and that it takes a whole process of understanding before the full significance of the new phenomena becomes clear".

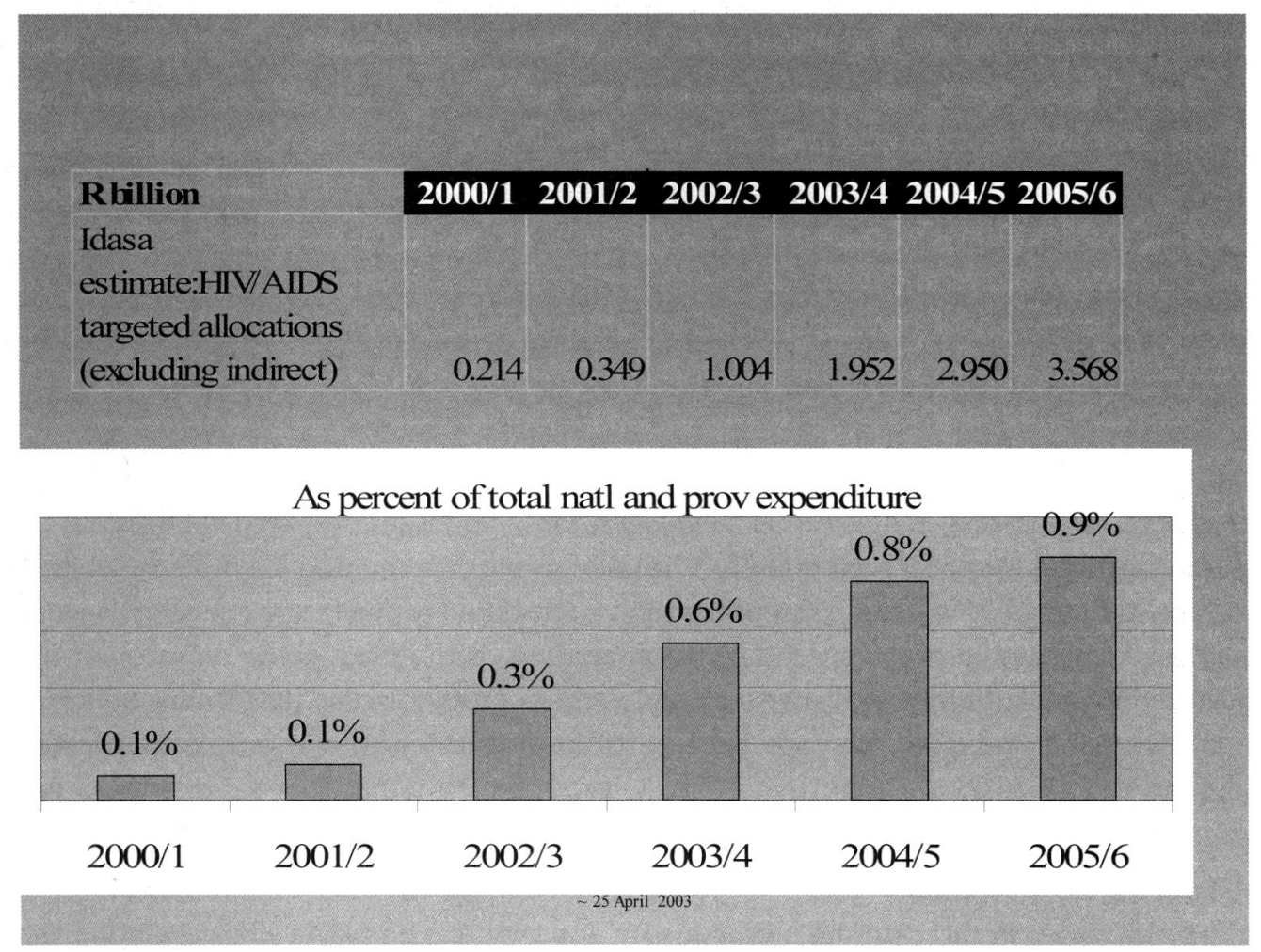

Figure 4 Funds set aside for HIV/AIDS interventions in national budget (Source: Hickey, 2003)

Generally, it can be observed that there has been an increase in the number of projects commenced and/or completed between 2000 and 2003 as shown in Fig 3, which provides a trend analysis of commencement, completion and publication of the research projects. A possible reason for such an increased interest on HIV/AIDS by researchers is the serious attention that the disease has lately generated from the government and foreign donors which has resulted in an increased funding that has been channeled to HIV/AIDS research. As shown in Fig. 4, South Africa has increasingly given attention to HIV/AIDS intervention programs. The amount of money allocated to HIV/AIDS intervention programs, for example, increased by R0.135 billion from R0.214 billion in 2000/200I financial year to R0.319 billion in 2001/2002 financial year. The total expenditure on HIV/AIDS is expected to be R3.569 billion this financial year (i.e. 2005/2006).

\subsection{Language of Empowerment}

Three languages, namely, Afrikaans, English, and Zulu were used to prepare the research projects. The results are as follows: Afrikaans (108), Afrikaans/English (I), English (765) and Zulu (I). It is interesting to note that despite the fact that IsiZulu is the most spoken home language in South Africa (Republic of South Africa, Department of Environmental Affairs and Tourism, 2003), it ranks third by recording the least number of records. The percentage distribution of home languages for the population of South Africa was estimated in 1994 to be as follows: isiZulu (22,4 \%), isiXhosa (17,5\%), Afrikaans ( $15,1 \%)$, Sepedi (9,8 \%), English (9,1 \%), Setswana (7,2 \%), Sesotho (6,9\%), Xitsonga (4,2 \%), siSwati $(2,6$ $\%)$, Tshivenda (I,7 \%), isiNdebele (I,5\%), Afrikaans/English (0,2\%), and other non-official languages (I,8 \%). Fig. 5 shows this distribution pattern. 


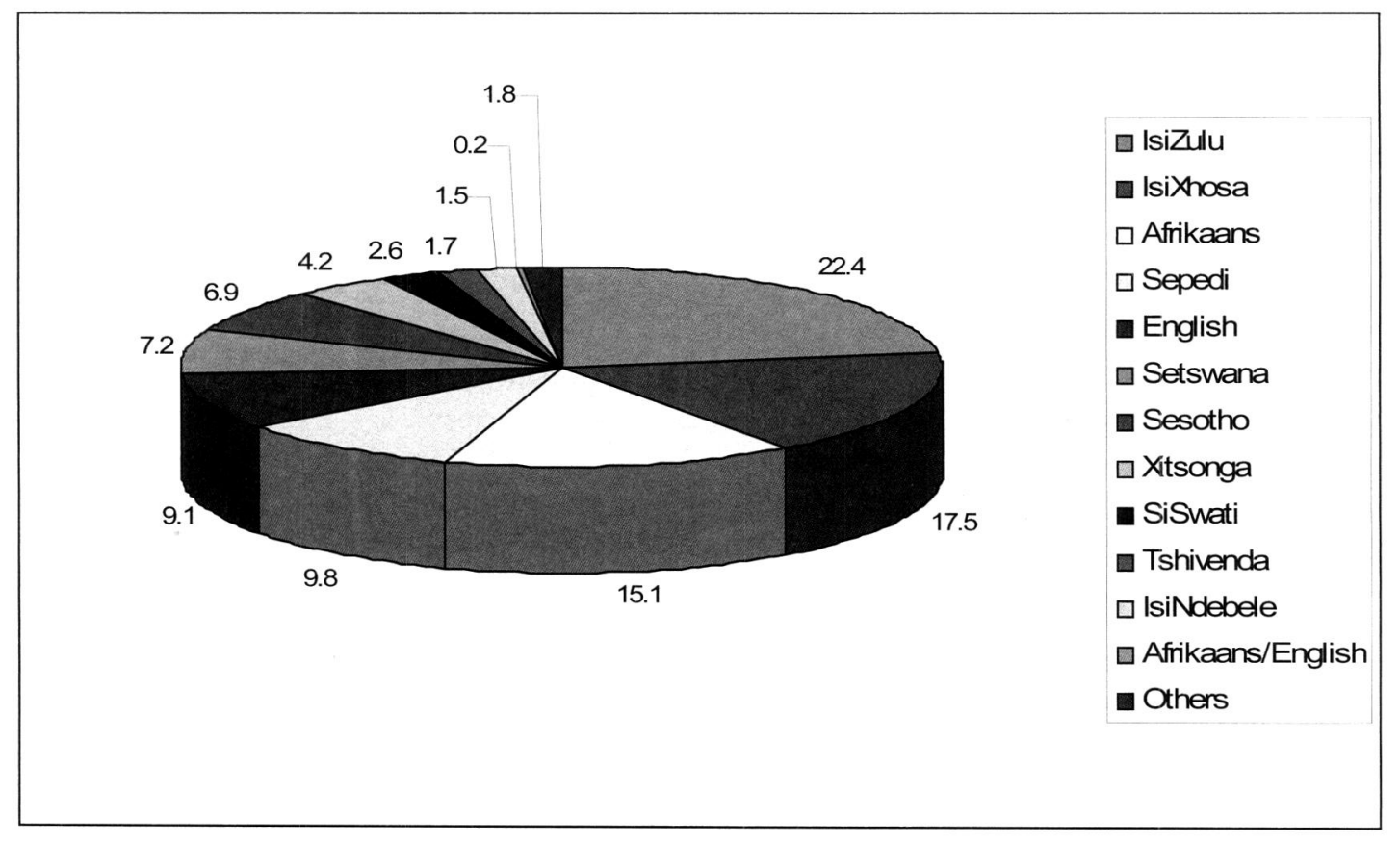

Figure 5 Distribution of home languages in South Africa (Source: Republic of South Africa, Department of Environmental Affairs and Tourism, 2003)

Ocholla (2000), too, noted an increase in the number of dissertations and theses prepared in English as opposed to those in other South African languages. He observed that English-based projects accounted for $80.28 \%$ while Afrikaans, which was on the decline, constituted $19.72 \%$. The discrepancy can be attributed to the fact that English language, which in this study was the most used language of preparing the research projects, is the most common medium of communication and language of instruction in institutions of higher learning. Ocholla (2000) argues that "more South Africans seem to write theses and dissertations in English, perhaps because of its popularity with regard to publication and scientific communication". Secondly, HIV/AIDS is a topic that is rarely discussed in mother tongues due to its sexual orientation. Sex, for a long time in Africa, could not be discussed publicly.

5.3 Institutions behind the empowerment

Academic institutions, which are in this case the universities in South Africa, do play a vital role in the fight against AIDS. Not only are they involved in actual research to find the cure for AIDS but they are also engaged in the preparation of candidates who in turn will assist in educating and training the community on the dangers of the disease and the preventive measures that can be taken in the fight against the pandemic. This study analyzed the publications by the institutions behind HIV/AIDS research and found that the most prolific institution was the University of South Africa, which posted I 40 records followed by the University of the Witswatersrand (I23), Rand Afrikaans University (108), and the University of Natal (106). The University of Pretoria ranked fifth with a total of 106 records while the University of Stellenbosch and Potchefstroom University of Christian Higher Education posted 80 and 62 records, respectively.

When categorized into two broad groups, notably the Historically Disadvantaged Institutions (HDI) and the Historically Advantaged Institutions (HAl), 9 out of the 10 top-ranked institutions were in the latter category, i.e. (HAl) as shown in Table I. The data distribution has been done for individual institutions before the merger of universities and technikons, an activity that was going on at the time of capturing data. Technikons' visibility was noted with Port Elizabeth Technikon leading the group with $5(0.53 \%)$ projects followed by Technikon Pretoria $(2,0.21 \%)$, Vaal Triangle Technikon $(\mathrm{I}, 0.11 \%)$ and Technikon South Africa is ranked number 20 with I project. Universities are therefore the leading producers of HIV/AIDS research projects most probably because research (both basic and applied) is commonly conducted at universities. Most universities require postgraduate masters and doctoral students to conduct research as one of the requirements for an award of the respective degrees. 
Table I Distribution by Institution and Database

\begin{tabular}{|c|c|c|c|c|c|c|c|}
\hline No. & Rank & Institution & Status & UCTD & C\&CR & TOTAL & $\%$ \\
\hline 1 & I & Univ. of South Africa & $\mathrm{HAl}$ & 5 & 135 & 140 & 14.57 \\
\hline 2 & 2 & Univ. of Wits & $\mathrm{HAl}$ & - & 123 & 123 & 12.80 \\
\hline 3 & 3 & Rand Afrikaans Univ. & HAI & 24 & 84 & 108 & 11.24 \\
\hline 4 & 4 & Univ. Of Natal & $\mathrm{HAl}$ & - & 106 & 106 & 11.03 \\
\hline 5 & 5 & Univ. of Pretoria & HAl & 19 & 61 & 80 & 8.32 \\
\hline 6 & 6 & Univ. of Stellenbosch & $\mathrm{HAl}$ & 19 & 43 & 62 & 6.45 \\
\hline 7 & 7 & Potchefstroom University for $\mathrm{CHE}$ & $\mathrm{HAl}$ & 3 & 45 & 48 & 4.99 \\
\hline 8 & 8 & Univ. of the Western Cape & HDI & 15 & 29 & 44 & 4.58 \\
\hline 9 & 9 & Univ. of Cape Town & $\mathrm{HAl}$ & 2 & 39 & 41 & 4.27 \\
\hline 10 & 10 & Univ. of Port Elizabeth & $\mathrm{HAl}$ & 7 & 33 & 40 & 4.16 \\
\hline 11 & 10 & Univ. of Zululand & HDI & - & 40 & 40 & 4.16 \\
\hline 12 & 11 & University of the Orange Free State & $\mathrm{HAl}$ & 4 & 26 & 30 & 3.12 \\
\hline 13 & 12 & Univ. of Durban-Westville & HDI & - & 17 & 17 & 1.77 \\
\hline 14 & 12 & Medical Univ. of S.A & HDI & - & 17 & 17 & I.77 \\
\hline 15 & 13 & Rhodes Univ. & $\mathrm{HAl}$ & 3 & 9 & 12 & 1.25 \\
\hline 16 & 14 & Univ. of the North-West & HDI & - & 7 & 7 & 0.73 \\
\hline 17 & 14 & Univ. of the North & HDI & - & 7 & 7 & 0.73 \\
\hline 18 & 15 & Univ. of Venda & HDI & - & 6 & 6 & 0.62 \\
\hline 19 & 15 & Human Sci. Research Council* & $\mathrm{n} / \mathrm{a}$ & - & 6 & 6 & 0.62 \\
\hline 20 & 16 & Port Elizabeth Tecknikon & $\mathrm{HAl}$ & - & 5 & 5 & 0.52 \\
\hline 21 & 17 & Milpark Business School * & $\mathrm{n} / \mathrm{a}$ & - & 4 & 4 & 0.42 \\
\hline 22 & 18 & Univ. of Transkei & HDI & - & 3 & 3 & 0.31 \\
\hline 23 & 18 & Medical Research Council* & $\mathrm{n} / \mathrm{a}$ & - & 3 & 3 & 0.31 \\
\hline 24 & 19 & Vista Univ. & HDI & 1 & 1 & 2 & 0.21 \\
\hline 25 & 19 & Tshwane University of Technology* & $\mathrm{n} / \mathrm{a}$ & - & 2 & 2 & 0.21 \\
\hline 26 & 19 & Technikon Pretoria & $\mathrm{HAl}$ & - & 2 & 2 & 0.21 \\
\hline 27 & 20 & Vaal Triangle Technikon & $\mathrm{HDI}$ & - & 1 & 1 & 0.10 \\
\hline 28 & 20 & Univ. of Fort Hare & HDI & - & 1 & I & 0.10 \\
\hline 29 & 20 & Technikon SA & $\mathrm{HAl}$ & - & I & I & 0.10 \\
\hline 30 & 20 & South African law Commission* & $n / a$ & - & I & I & 0.10 \\
\hline 31 & 20 & Foreign University* & $\mathrm{n} / \mathrm{a}$ & - & 1 & 1 & 0.10 \\
\hline \multirow[t]{2}{*}{32} & 20 & Durban Institute of Technology* & $\mathrm{n} / \mathrm{a}$ & - & 1 & 1 & 0.10 \\
\hline & & TOTAL & & 102 & 859 & 961 & 100 \\
\hline
\end{tabular}

*The classification used here to group the institutions into the two categories cannot be applied to these institutions

5.4 Individuals behind the empowerment: "study leaders" and "students"

A total of 877 people participated in conducting HIV/AIDS research in South Africa between 1986 and 2004. These included the masters and doctorate students as well as individuals who conducted research for purposes other than qualification for an award of an academic degree.

Of particular interest to this study are the individuals who were behind the students' preparedness, otherwise known as supervisors or study leaders. Essentially, these persons are involved in all the stages of the research being conducted, right from the preparation of the research proposal to the compilation of the intended publication. In addition, they sometimes do influence the sponsorship of the research in terms of facilitating securing of grants and research funds. They can be said therefore to have fully participated in the actual research. In fact, they usually end up being co-authors of papers generated from such research activities (Ocholla, 2000). This study analyzed 416 records (in C\&CR) that provided names of "study leaders". An integer (whole or complete) count approach was used to assign publications to individual "study leaders". Results indicate that there were a total of 364 study leaders as shown in Table 2 and Appendix I. Leading at the top of the two Tables is JPJ Theron who has led, so far, in eight projects followed by AD Stuart, H Strydom and I Eloff who have each supervised as well as actively participated in 7 projects. Ranking $3^{\text {rd }}$ and $4^{\text {th }}$ in Table 2 are AA van Nierkark and HG Pretorius, each with 6 projects and E Kotze and JP Fouche who yielded 5 records each. 
Table 2 Study Leaders with two or more publications

\begin{tabular}{|c|c|c|c|c|c|c|c|c|}
\hline Rank & Name & No. of projects & Rank & Name & No. of projects & Rank & Name & No. of projects \\
\hline I & Theron JPJ & 8 & 6 & Dorfling CS & 3 & 7 & Olivier MP & 2 \\
\hline 2 & Stuart AD & 7 & 6 & De Witt MW & 3 & 7 & Nzimande D & 2 \\
\hline 2 & Strydom H & 7 & 6 & Alexander P & 3 & 7 & Noyoo N & 2 \\
\hline 2 & Eloff I & 7 & 7 & Wolfraadt JA & 2 & 7 & Naude H & 2 \\
\hline 3 & Van Niekerk AA & 6 & 7 & Willem-Belot PS & 2 & 7 & Morrell R & 2 \\
\hline 3 & Pretorius HG & 6 & 7 & Willem P & 2 & 7 & Monama EN & 2 \\
\hline 4 & Kotze E & 5 & 7 & Werner A & 2 & 7 & Mogotlane SM & 2 \\
\hline 4 & Fouche JP & 5 & 7 & Ward ED & 2 & 7 & Manala MI & 2 \\
\hline 5 & Potgieter EE & 4 & 7 & Vorster $\mathrm{HH}$ & 2 & 7 & Makhubela-Nkondo ON & 2 \\
\hline 6 & Van Rensburg GH & 3 & 7 & Von der Marwitz J & 2 & 7 & Lubbe GJA & 2 \\
\hline 6 & Van Dyk AC & 3 & 7 & Viljoen FJ & 2 & 7 & Louw B & 2 \\
\hline 6 & van der Walt JA & 3 & 7 & Van Wyk C & 2 & 7 & Litheko SRS & 2 \\
\hline 6 & Van der Wal DM & 3 & 7 & Van Rooyen C & 2 & 7 & Liebenberg A & 2 \\
\hline 6 & Tomaselli KG & 3 & 7 & Tshiwula JL & 2 & 7 & Lawrence RB & 2 \\
\hline 6 & Thornton RJ & 3 & 7 & Taute FM & 2 & 7 & Ichharam M & 2 \\
\hline 6 & Samuel M & 3 & 7 & Sparks BLW & 2 & 7 & Hattingh SP & 2 \\
\hline 6 & Roux JP & 3 & 7 & Spangenberg J & 2 & 7 & Groenewald PCN & 2 \\
\hline 6 & Prinsloo E & 3 & 7 & Smit $R$ & 2 & 7 & Greeff M & 2 \\
\hline 6 & Pettifor J & 3 & 7 & Smit JA & 2 & 7 & Ganga-Limando $M$ & 2 \\
\hline 6 & Mendelow BV & 3 & 7 & Siopis PA & 2 & 7 & Ebrahim AFM & 2 \\
\hline 6 & Mavundla TR & 3 & 7 & Sibanda $T$ & 2 & 7 & De Beer S & 2 \\
\hline 6 & Maharaj P & 3 & 7 & Shefer $\mathrm{T}$ & 2 & 7 & Davel CJ & 2 \\
\hline 6 & Lindegger G & 3 & 7 & $\underline{\text { Sekudu } /}$ & 2 & 7 & Cowling LJ & 2 \\
\hline 6 & Kotze DJ & 3 & 7 & Schoeman JB & 2 & 7 & Chikte UME & 2 \\
\hline 6 & King 니 & 3 & 7 & Schneider $\mathrm{H}$ & 2 & 7 & Carstens PA & 2 \\
\hline 6 & Joubert JPR & 3 & 7 & Roux AA & 2 & 7 & Carbonatto $\mathrm{CL}$ & 2 \\
\hline 6 & Herbst MS & 3 & 7 & Pienaar AJ & 2 & 7 & Botha NA & 2 \\
\hline 6 & Ehlers VJ & 3 & 7 & Perold A & 2 & 7 & Botes AC & 2 \\
\hline 6 & Du Plessis GE & 3 & 7 & Patel L & 2 & 7 & Asher A & 2 \\
\hline 6 & Du Plessis E & 3 & 7 & Orr JP & 2 & 7 & Alberts UU & 2 \\
\hline
\end{tabular}

On overall, "study leaders" who produced two or more research projects numbered 90 while those with one project each totaled 274, meaning therefore that majority of the "study leaders" produced one publication (or candidate) each. It would be interesting to find out the reasons behind such a distribution by considering the participants' educational background, racial affiliation, occupation and even gender to find out if the disparity in their productivity is influenced or determined by any of these factors. According to O'Connor \& Voos (198I) author productivity is a function of several influencing factors which can be grouped into two major conceptual areas, notably, an author's personal characteristics and the author's environment or situation. Personal characteristics would include such issues as intelligence, achievement, personality and expectations while colleagues, availability of information, the problem under investigation and the author's field or discipline are environmental or situational factors that can cause variations in authors' productivity. Other internal motivational factors that can create differences in author productivity include "tenure and promotion requirements for college and university faculty" (O'Connor \& Voos, 1981: I3).

This study, however, did not investigate the reasons that could have explained why some individuals were more prolific than the majority who produced one project each but it has been argued that any or several of the aforementioned factors can influence author productivity. For instance, Jacobs (2002) acknowledges that during the apartheid system of governance in the country, the HDI were discriminated against especially in the allocation of funds and state support for various activities including research work in science and technology - that were mostly allocated on racial grounds. She further observes that "most of these institutions were isolated physically, politically, and academically, hence it was far more difficult to establish an infrastructure for research or attract renowned academics to work in these institutions" and "consequently, the productivity in some of the scientific fields in some institutions lagged behind others". 
Factors such as the academic position (i.e. professor, associate professor, etc.) number of years in the field, and hope for promotion besides the prestige of the institution do influence productivity (Jacobs, 200I).

Table 3 Study leaders by their Institution (University) and Department of affiliation

\begin{tabular}{|c|c|c|c|}
\hline Rank & Name & Institution & Department \\
\hline 1 & Theron JPJ & University of South Africa & Dept of Practical Theology \\
\hline 2 & Stuart AD & Rand Afrikaans University & Dept of Psychology \\
\hline 2 & Strydom H & Potchefstroom University for $\mathrm{CHE}$ & School of Psychological Behavioral Sciences \\
\hline 2 & Eloff I & University of Pretoria & Dept of Educational Psychology \\
\hline 3 & van Niekerk AA & University of Stellenbosch & Centre for Applied Ethics \\
\hline 3 & Pretorius HG & Rand Afrikaans University & Dept of Psychology \\
\hline 4 & Kotze E & University of South Africa & Dept of Practical Theology \\
\hline 4 & Fouche JP & University of Port Elizabeth & Dept of Psychology \\
\hline 5 & Potgieter EE & University of Port Elizabeth & Dept of Psychology \\
\hline 6 & Van Rensburg GH & University of South Africa & Dept of Health Studies \\
\hline 6 & Van Dyk AC & University of South Africa & Dept of Psychology \\
\hline 6 & van der Walt JA & University of Port Elizabeth & Faculty of Law \\
\hline 6 & Van der Wal DM & University of South Africa & Dept of Health Studies \\
\hline 6 & Tomaselli KG & University of Natal & Graduate Program in Cultural and Media Studies \\
\hline 6 & Thornton RJ & University of the Witwatersrand & Dept of Social Anthropology \\
\hline 6 & Samuel M & University of Durban-Westville & School of Educational Studies \\
\hline 6 & Roux JP & University of South Africa & Dept of Practical Theology \\
\hline 6 & Prinsloo E & University of South Africa & Dept of Educational Studies \\
\hline 6 & Pettifor J & University of the Witwatersrand & Dept of Pediatrics and Child Health \\
\hline 6 & Mendelow BV & University of the Witwatersrand & Dept of Molecular Medicine and Hematology \\
\hline 6 & Mavundla TR & University of South Africa & Dept of Health Studies \\
\hline 6 & Maharaj P & University of Natal & Faculty of Human Sciences. Program: Sociology \\
\hline 6 & Lindegger G & University of Natal & School of Psychology \\
\hline 6 & Kotze DJ & University of South Africa & Dept of Practical Theology \\
\hline 6 & King LJ & University of South Africa & Dept of Health Studies \\
\hline 6 & Joubert JPR & University of South Africa & Dept of Industrial and Organisational Psychology \\
\hline 6 & Herbst MC & University of South Africa & Dept of Health Studies \\
\hline 6 & Ehlers VJ & University of South Africa & Dept of Health Studies \\
\hline 6 & Du Plessis GE & University of South Africa & Dept of Sociology \\
\hline 6 & Du Plessis E & University of Natal & School of Psychology \\
\hline 6 & Dorfling CS & Rand Afrikaans University & Dept of Nursing \\
\hline 6 & De Witt MW & University of South Africa & Dept of Educational Studies \\
\hline 6 & Alexander $\mathrm{P}$ & Rand Afrikaans University & Dept of Sociology \\
\hline
\end{tabular}

In his study on research capacity in library and information science in South Africa, Ocholla (2000), too, observed that a large proportion of graduate research was produced in LIS departments located in the previously Historically Advantaged universities and that the white race was the most productive. These observations were also noted in the current study as shown in Table I. Table 3 makes similar revelations, i.e. individuals in the HAl were ranked higher than their counterparts in the $\mathrm{HDI}$ and that most individuals were from the white race. Names of study leaders from the black community are highlighted (in bold and underlined) in Tables I, 2 and 3. It can therefore be argued that situational or environmental factors (such as academic, colleagues, institution, etc.) can influence one's productivity. Further research, however, is recommended to determine to what extent these factors impact on HIV/AIDS researchers' productivity and impact in South Africa.

\subsection{Information sources for empowerment}

It has often been argued that information is power. Cliff (1999) opines that intentional, ongoing, expansive, many-to-many communication within the context of organized accurate, up-to-date information is power. Commenting about the power of information in firms, Knights (2004) observes that information is power that can be used to run one's plant and machines better and more profitably and because such information is very valuable, Knights explains that today's process and production monitoring systems have increasingly endeavored to put that information in the palm of our 
hands. There is therefore no limit to what anyone with the right information can do with it. Gupta (2000), while investigating the approaches to empowering women in the AIDS era, says that educating women should also involve providing them with the information they need about their bodies and sex since information is power and women have the right to receive it. Finally, in his speech at the Media Leaders Summit in India on the Role of the media for HIV/AIDS prevention, the then Indian Prime Minister summarized the importance of information in empowering an individual as well as the entire community. He observed that:

'In this campaign the media plays an important and determining role in educating the public, creating awareness among them and transmitting crucial information so that people become aware, remain alert and take measures to prevent its occurrence. We all know that information is power, and that awareness therefore empowers' (AIDSRadio, 2005)

The current study analyzed documents by the intended publication or publication type to identify the type of publications, as indexed in the two databases, that the South African community can use to find information that can empower it in the AIDS war. Using a complete count approach, this study found that majority of the records were in form of dissertations and theses (754) followed by reports (70), journal articles (25), conference papers (22), Books and chapters in books (9), databases (5), and computer software (2). Others were videos and posters, which recorded one ( 1 ) entry each. Apparently and as expected, the theses and dissertations were the majority and this can be attributed to the usage of UCTD and C\&CR databases whose large percentage of the indexed items are theses and dissertations. Whereas the UCTD indexes only theses and dissertations, C\&CR contains masters and doctoral theses as well as information on other research projects. The variety of documents that carried AIDS information augurs well for the HIV/AIDS intervention workers, educators, counselors, researchers, and medical practitioners, just to name a few.

\subsection{Purposes for which candidates were prepared/empowered}

The purpose for which the research projects were undertaken was two-fold. The purpose was either for qualification for an academic award or non-qualification or for purposes of an award of a masters or doctorate degree. This second reason for data analysis provided data on the quality of the candidates. Quality here is measured by the level of study, i.e. Masters or Doctorate. This study found that there were 147 non-qualification research projects whose findings were presented in the form of training events, reports, journal articles, databases, conference papers, books and chapters in books, software, videos and posters. Eight hundred thirty four research projects were taken for purposes of an award of either a masters or doctoral degree. Research projects conducted at the Masters level were the majority (608) while those conducted at the Doctoral level numbered 122. Masters dissertations were the dominant publication types followed by doctoral dissertations/theses and articles, in that order. Similar observations were made by Ocholla (2002). The author noted that graduate research was dominated by master's work, which accounted for $82 \%$ of the total 218 records analyzed while doctoral research yielded 38 (18\%) documents. The gradual growth of Masters Projects may be attributed to the competitive job opportunities. Current job advertisements that require a first degree holder would add the phrase "a higher degree or academic qualification will be an added advantage", a situation that has prompted first degree holders to pursue further studies in order to compete favorably in the job market that is increasingly becoming not only competitive but limited in the number of vacancies to be filled. There are an increasing number of first degree holders who are presently enrolling for the Masters degree programs at various universities in and outside the continent of Africa, hence the large number of Masters Dissertations indexed in the C\&CR and UCTD as opposed to the doctoral projects.

\subsection{Areas/sectors of empowerment}

Publications were analyzed according to the subject terms used to index the HIVIAIDS records in the UCTD and C\&CR databases, the subject codes, and subject sub-fields for three purposes, notably:

I. to determine the areas of empowerment,

2. to examine the type of professionals that are and would be involved in the fight against the disease and

3. to evaluate the multi-disciplinarity of HIV/AIDS

As expected and as shown in Table 4, majority of projects were conducted in the subject area of Medical Sciences, which yielded 195 (22.49\%) records followed by Psychology (I 73 or 19.95\%), Education (76 or $8.77 \%$ ) and Social work (72 or $8.30 \%)$ while Sociology, Health Sciences and Religion are ranked $5^{\text {th }}, 6^{\text {th }}$ and $7^{\text {th }}$ with $59(6.81 \%), 56(6.46 \%)$, and 49 $(5.65 \%)$, respectively. Others - with 10 or more projects - in descending order - include Business Administration (33), Law (26), Communication Science (19), Anthropology (15), and Economics (12). There were a total 4 I subject fields in which HIV/AIDS research was conducted.

The Fields that produced three and less records include Speech science, Microbiology, Library Science, Development administration, Cultural studies, Criminology, and History. Others include Human and Regional Geography, 
Environmental sciences, English literature, Zulu language, Town and regional planning, Sex psychology, Linguistics, Nursing with respect to specific diseases, Gender studies, Food science and technology, Engineering, Classics, Biotechnology, and Agriculture. An analysis of the records by subject/topic indicated that majority of the projects were conducted in the field of Medical and Health Sciences which, when combined, posted $25 \mathrm{I}$ projects. This figure includes the projects that were undertaken for non-qualification purposes.

Table 4 Distribution of records by subject indicating multidisciplinarity of HIV/AIDS research

\begin{tabular}{lcclcc}
\hline \multicolumn{1}{c}{ Subject } & Number of records & $\%$ & \multicolumn{1}{c}{ Subject } & Number of records & $\%$ \\
\hline Medical Sciences & 195 & 22.49 & Microbiology & 3 & 0.35 \\
Psychology & 173 & 19.95 & Library Science & 3 & 0.35 \\
Education & 76 & 8.77 & Development administration & 3 & 0.35 \\
Social work & 72 & 8.30 & Cultural studies & 3 & 0.35 \\
Sociology & 59 & 6.81 & Criminology & 3 & 0.35 \\
Health Sciences & 56 & 6.46 & History & 2 & 0.23 \\
Religion & 49 & 5.65 & Geography, human and regional & 2 & 0.23 \\
Business administration & 33 & 3.81 & Environmental sciences & 2 & 0.23 \\
Law & 26 & 3.00 & English literature & 2 & 0.23 \\
Communication Science & 19 & 2.19 & Zulu language & 1 & 0.12 \\
Anthropology & 15 & 1.73 & Town and regional planning & 1 & 0.12 \\
Economics & 12 & 1.38 & Sex psychology & 1 & 0.12 \\
Mathematics & 1.04 & Nursing with respect to specific... & 1 & 0.12 \\
Political Science & 8 & 0.92 & Linguistics & 1 & 0.12 \\
Philosophy & 8 & 0.81 & Gender studies & 1 & 0.12 \\
Public Administration & 7 & 0.58 & Food science and technology & 1 & 0.12 \\
Performing arts & 5 & 0.46 & Engineering & 1 & 0.12 \\
Information Science & 4 & 0.46 & Classics & 1 & 0.12 \\
Fine arts & 4 & 0.46 & Biotechnology & 1 & 0.12 \\
Biochemistry & 4 & 0.46 & Agriculture & 1 & 0.12 \\
Speech science & 4 & 0.35 & & & \\
\hline & 3 & & &
\end{tabular}

\section{Conclusions}

This study draws the following generalized conclusions based on the findings outlined in Section 5.

The number of the research projects has continued to increase over the years, seemingly, because of increased funding from governmental and non-governmental organizations and donors. Each subsequent year has recorded a higher number of candidates researching HIV/AIDS than the previous one. Production and training of candidates, therefore, has continued to grow, so is the revitalizing of the HIV/AIDS intervention workforce. However, the percentage increase has been surprisingly low when compared to the increasing trend of the HIV infection prevalence.

Universities as compared to other institutions yielded most of research projects and therefore were the most productive. But even within the category of universities, research was mainly centered in the previously "Historically Advantaged" universities. Technikons (renamed Universities/Institutions of Technology) were fairly active in graduate preparedness.

The quality of the candidates (human resources) that are trained in or produced by the training institutions was measured by the level of education. It should be noted however, that the level of education (Bachelors, Masters, or PhD) is only one way of measuring the quality of candidates. Experience, skills, and intelligence are among the other indicators of quality that were not explored in this study. Nevertheless, it was found that majority of studies were conducted at Masters Level of education while there was a favorable representation from the Doctorate candidates. Although it is very important to concentrate research on HIV/AIDS in academic institutions as shown by the number of projects that are generated in these institutions, it is equally important to direct the government's resources to self-initiated projects for non-academic qualification purposes.

Publications are channels of communicating the research findings to the community and therefore form a strong component of the tools of empowering the community in the AIDS war. As sources of information for empowerment, publications were analyzed according to the document types in order to examine the role that they can play in arresting the increasing cases of HIV prevalence. We all know that AIDS awareness is the biggest challenge facing the AIDS campaigns. Stigmatization and other negative effects of HIV/AIDS can only be defeated through organized and well- 
coordinated awareness campaigns. The provision of relevant publications such as videos, books, dissertations, and theses will supplement other campaign strategies that are geared towards the fight against HIV/AIDS. Information is power and if utilized efficiently and effectively can empower the South African community in several ways such as creating awareness and improving further research, just but to name a few. Most publications were in form of theses and dissertations. The introduction of the United Catalog of Theses and Dissertations is welcome but the records found indexed therein were a small percentage of those produced annually. The database publishers should endeavor to collect and index all theses and dissertations produced in the country. This study could not find out the reasons for the low coverage in UCTD, but if it is because most theses and dissertations are not published, then the institutions should consider formulating rules that require candidates to publish their theses and dissertations as a requirement for an award of the degree. This will go a long way to improving the quality of these works.

Most candidates (i.e. masters and doctoral students) were being prepared to work in the medical and health sectors implying that the most empowered sector in the South African HIV/AIDS workforce is the medical and health sector. Other equally important sectors that have been re-energized or strengthened in the fight against the disease are culture and social services, education, and the judiciary (or the BAR). Concerning profession, candidates are being prepared to work as medical doctors, clinicians, health workers, community health nurses, nurses, pharmacists, medical laboratory technicians, etc. Besides the medical and health workers, other professionals that universities have prepared or are preparing include social workers, educationists (teachers, lecturers, curriculum developers and assessors, etc.), mathematicians and statisticians, economists, counselors, the clergy, lawyers/advocates, and Library and information scientists, among others. The identification of a sizable number of projects generated from such subject areas as social work and education implies that the country's emphasis may have been placed on social work with HIV/AIDS patients and in educating her people about the spread and prevention of the disease.

More candidates are registering for training in different disciplines and sub-disciplines in which HIV/AIDS research is becoming a research front, rendering the subject domain of HIV/AIDS a multidisciplinality impetus or outlook. Multidisciplinarity of HIV/AIDS is reflected in the varied and several disciplines in which the masters and doctoral students are trained.

As regards the individuals behind the empowerment exercise, "study leaders" from the Historically Advantaged Institutions were the most productive. Even within this group, individuals from the White race were the most dominant as compared to their black counterparts.

The most preferred language of publication (and hence empowerment) was English. The local languages (numbering 10) are rarely used except for Afrikaans, which showed up more frequently than the rest of the languages.

In conclusion, an informetric analysis of research outputs can be used to determine the quality as well as the quantity of the research/educational outcomes at academic institutions at any given time frame. A country's top decision-making organs and her responsible departments may use such findings to project employment and evaluate her workforce capacity. Regarding the institutions that prepare the students, informetric analyses may assist in improving the quality of the educational programs on HIV/AIDS.

We therefore recommend the following:

I. Every university and institution of higher learning should be required to include HIV/AIDS education in its curriculum. As Otieno (2004) observes, "courses taught in universities and specialized seminars, as well as media efforts, can serve as a conduit for raising awareness".

2. Both academic and public libraries consider digitizing the theses and dissertations that are produced in the country. Apart from storing the bound research projects, they should endeavor to digitize especially the theses and dissertations as this would improve their visibility and usability and hence further research in HIV/AIDS. The libraries can deposit the digitized theses and dissertations in a publicly accessible website, preferably an Open Archives Initiative (OAI)-compliant E-print Archive, a process that is commonly referred to as selfarchiving. Depositing involves a simple web interface where the depositors copy/pastes in the "metadata" (date, author-name, title, journal-name, etc.) and then attaches the full-text document (EPrints.org, 2005). Although the following statement applies to peer-reviewed research output, it nevertheless would apply to dissertations and theses. "The purpose of self-archiving is to make the full text of the peer-reviewed research output of scholars/scientists and their institutions visible, accessible, harvestable, searchable and useable by any potential user with access to the Internet. The purpose of thus maximizing public access to research findings online is that this in turn maximizes its visibility, usage and impact -- which in turn not only maximizes its benefits to researchers and their institution in terms of prestige, prizes, salary, and grant revenue but it also maximizes its benefits to research itself (and hence to the society that funds it) in terms of research dissemination, application and growth, hence research productivity and progress. This is why open access is both optimal and inevitable" (Eprints.org, 2005). 
3. In order to assist in the improvement of further informetric studies, the National Research Foundation of South Africa, which is responsible for indexing the C\&CR, and the North-West University can take note of the following:

- Standardization of names of authors (both research leaders and followers)

- Construction of a database that specifically indexes HIV/AIDS research in South Africa. It was a bit problematic to extract all AIDS records since the index term "AIDS" is ambiguous.

- Re-edit and update the database regularly in order to clean the indexed data, e.g. removing the duplicates especially in the C\&CR.

4. Further research is recommended to examine the quality and international visibility of the AIDS research projects as produced in South Africa. In addition, an analysis of HIV/AIDS research using other bibliographic databases (e.g. UMI ProQuest) that index theses and dissertations produced in other countries is highly recommended for purposes of comparison.

\section{Declaration and acknowledgement}

Versions of this paper were presented at the $6^{\text {th }}$ DLISLISA Conference at the University of Zululand on $2^{\text {nd }}$ September 2005 (see $h t t p: / / w w w . l i s . u z u l u . a c . z a / r e s e a r c h . h t m I \# d l i s l i s a$ ) and at the $8^{\text {th }}$ Annual LIASA conference held at Nelspruit $26^{\text {th }}$ -

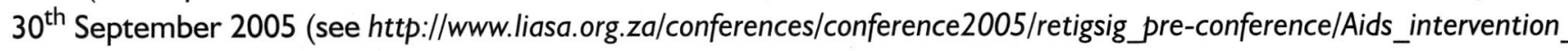
Onyancha_2005.pdf). Support from Prof. DN Ocholla, the University of Zululand and the University of Eastern Africa, Baraton is hereby acknowledged.

\section{References}

AIDS Foundation of South Africa. (2003). AIDS in South Africa. Retrieved March I5 th 2005 from http://www.aids.org.za/

AIDSRadio. (2005). Indian Prime Minister's speech on the role of media for HIV/AIDS prevention. Retrieved August $24^{\text {th }}, 2005$ from $h$ ttp://www.aidschannel.org/article/view/78650/II

Begley, S., Check, E., Wingert, P., \& Conway, F. (200I). AIDS at 20. Newsweek, 137:(24), 34

Bierbaum, E.G., \& Brooks, T.A. (1995). The literature of Acquired Immunodeficiency Syndrome (AIDS): continuing changes in publication patterns and subject access. Journal of the American Society for Information Science, 46(7):530-536

Chan, L. C. Y., Jin, B., Rousseau, R., Vaughan, L. \& Yu, Y. (2003). Newspaper Coverage of SARS: a comparison among Canada, Hong Kong, Mainland China and Western Europe. Cybermetrics: International Journal of Scientometrics, Bibliometrics and Informetrics, v. 6/7 (I), paper I. Retreived January $17^{\text {th }}, 2005$, from http://www.cindoc.csic.es/cybermetrics/articles/v6ilpI.html

Clift, S. (1999). Information is Power? Envisioning the Minnesota Public Internet - Public service and community information and interaction in the public interest. Retrieved August $24^{\text {th }}, 2005$, from $h t t p: / / w w w . p u b l i c u s . n e t / p r e s e n t / p u b l i c /$

Diodato, V. (1994). Dictionary of Bibliometrics. New York: Haworth.

Dube, L. \& Ocholla, DN. (2005). Insight into the management and diffusion strategies of HIV/AIDS information in institutions of higher education in South Africa. South African Journal of Libraries and Information Science, 7 I (2): 187-200

EPrints.org. (2005). EPrints - Self-Archiving FAQ. Retrieved August $25^{\text {th }}$, 2005, from http://www.eprints.org/openaccess/self-faq/ \#self-archiving

Gupta, G. R. (2000). Approaches for Empowering Women in the HIV/AIDS Pandemic: a gender perspective. Retrieved August $25^{\text {th }}, 2005$, from http://www.un.org/womenwatch/daw/csw/hivaids/Gupta.html

$\mathrm{He}$, S. (200I). Geographic distribution of foreign authorship in LIS journals. A comparison between JASIST and Journal of Documentaion. In: M. Davis \& C.S. Wilson (eds.). Proceedings of the 8th International Conference on Scientometrics and Informetrics, Sydney, I6-20 July 200I, 2, 235-243.

Hertzel, D. (1987). Bibliometrics, history of the development of ideas in: statistical bibliography or bibliometrics? In: Kent, A. \& Lancour H., (Eds). Encyclopaedia of Library and Information Science, 42: I44-219.

Hickey, A. (2003). Public expenditure on HIV/AIDS in South Africa. Retrieved August 24 ${ }^{\text {th }}$, 2005, from www.ksg.harvard.edu/cbg/ hiv-aids/Durban/Alison\%20Hickey.ppt

Hood, W.W. \& Wilson, C.S. (200I). The literature of bibliometrics, scientometrics, and informetrics. Scientometrics, 52(2):291314

Huber, J.T., Gillaspy, M.L. \& Fogel, S.C. (2000). Evolution in the body of HIV nursing knowledge. Medical Reference Services Quarterly, I9(I):3I-45.

Jacobs, D. (2001). A bibliometric study of the publication patterns of scientists in South Africa 1992-96, with special reference to gender difference. In: M. Davis \& C.S. Wilson (eds.). Proceedings of the 8th International Conference on Scientometrics and Informetrics, Sydney, 16-20 July 200I, 2, 275-285

Jacobs, D. (2000). Institutional status, funding and grading in relation to faculty research productivity. In I. Wormell (ed.). ProLISSA 2000. Proceeding of the Ist biennial ProLISSA Conference, Pretoria, 26 - 27 October 2000. Pretoria: CID University of Pretoria, pp. 143 - 156.

Knights, M. (2004). Information Is Power. Retrieved August 24th, 2005, from http://www.plasticstechnology.com/articles/ $200404 \mathrm{fal} . \mathrm{html}$

Konforti, B. (200I). Twenty years ago. Nature Structural Biology, 8(7): 582

Macias-Chapula, C.A. (2000). AIDS in Haiti: a bibliometric analysis. Medical Library Association. Bulletin, 88(I):56-6I.

Macias-Chapula, C. A. \& Mijangos-Nolasco, A. (2002). Bibliometric analysis of AIDS literature in Central Africa. Scientometrics, 54 (2), 309-317. 
Macias-Chapula, C.A., Sotolongo-Aguilar, G.R., Magde, B., \& Solorio-Lagunas. (1999). Subject analysis of AIDS literature, as produced in Latin America and the Caribbean. Scientometrics, 46(3):563-574

Mackenzie, S. (2000). Scientific silence: AIDS and African-Americans in the medical literature. American Journal of Public Health, 90(7): II $145-1146$.

Moed, H.F. (2002). The impact-factors debate: the ISI's uses and limits. Nature, 415:73I-732

Narvaez-Berthelemot, N., Russell, J. M., Arvanitis, R., Waast, R., \& Gaillard, J. (200I). Science in Africa: an overview of mainstream scientific output. In: M. Davis \& C.S. Wilson (eds.). Proceedings of the 8 th International Conference on Scientometrics and Informetrics, Sydney, 16-20 July 200I, 2, 469-476.

National Institute of Allergy and Infectious Diseases (NIAID). (2003). General Information about HIV/AIDS Treatment. Retrieved February $4^{\text {th }}, 2005$, from http://www.niad.nih.gov/daids/therapeutics/geninfo/geninfo.htm\# I

Nicholas, D. \& Ritchie, M. (1978). Literature and bibliometrics. London: Clive Bingley.

Ocholla, D. N. (2000). Research capacity in Library and Information Science in South Africa - an overview. Paper delivered at the 66th IFLA Council and General Conference, Jerusalem, Israel, 13th-18th August 2000. Retrieved February $4^{\text {th }}, 2005$, from http://www.ifla.org//V/ifla66/papers/054-127e.htm

O’Connor, D.O. \& Voos, H. (198I). Empirical laws, theory construction and bibliometrics. Library Trends, 30:9-20

Onyancha, O.B. \& Ocholla, D.N. (2004). A Comparative Study of the Literature on HIV/AIDS in Kenya and Uganda: a Bibliometric Study. Library \& Information Science Research, vol. 26(2004): 434-447

Otieno, A. (2004). The Role of Education in Promoting Health and Human Rights. Retrieved August 24 ${ }^{\text {th }}, 2005$, from http:// www.un.org/Pubs/chronicle/2004/issue2/0204p50.asp

Pratt, G.F. (1992). A Decade of AIDS Literature. Bulletin of the Medical Library Association, 80(4):380-38I

Republic of South Africa, Ministry of Education. (2002). Press statement by the Minister of Education, Professor Kader Asmal, MP, on the transformation and reconstruction of the higher education system. Retrieved August $20^{\text {th }}$, 2005, from http:// www.info.gov.za/speeches/2002/02053016/1/003.htm

Republic of South Africa, Ministry of Education. (2005). About - HIV/AIDS in Education. Retrieved August $12^{\text {th }}, 2005$, from http://education.pwv.gov.za/mainActivities. asp?src = dire\&xsrc = haai

Republic of South Africa, Department of Environmental Affairs and Tourism. (2003). Language distribution. Retrieved on $16^{\text {th }}$ March 2005 from http://www.environment.gov.za/Enviro-Info/nat/lang.htm

The Scientist. (1996). Citation analysis reveals leading institutions, scientists researching AIDS. The Scientist, I2-I3

The South African Universities Vice-Chancellors Association, Higher Education HIVIAIDS Programme, (2004). HIV and AIDS audit: Interventions in South African Higher Education. Pretoria: Higher Education HIV/AIDS Programme.

Turnbull, D. (2000). Bibliometrics and the Worldwide Web. Retrieved March $18^{\text {th }}, 2002$, from http://donturn.fis.utoronto.ca/ research/bibweb.html

UNAIDS. (2003). AIDS epidemic update, December 2003. Retrieved December $9^{\text {th }}, 2003$, from http://www.unaids.org

UNAIDS. (2004). 2004 Report on the global AIDS epidemic. Retrieved March 4th, 2004, from http://www.unaids.org

Ungern-Sternberg, S. (1995). Applications in teaching bibliometrics. Proceedings of the $61^{\text {st }}$ IFLA General Conference, $20^{\text {th }}-25^{\text {th }}$ August. Retrieved February $20^{\text {th }}, 2002$, from $h t t p: / / w w w . i f l a . o r g / / V / f l a 6 / / 6 I-u n g s . h t m$ 
Appendix I Study Leaders with one publication each

\begin{tabular}{|c|c|c|c|c|c|c|}
\hline Abotsi EK & De Kock DM & Guy 10 & Lessing $N$ & Myburgh CPH & Robertson B & Urbani G \\
\hline Adejumo 0 & De Ridder JH & Guy $O$ & Lotter GA & Myburgh NG & Roestenburg W & Uys $\mathrm{F}$ \\
\hline Ahwireng-Obeng $\mathbf{F}$ & De Ridder JH & Haffajee S & Louw J & Naidoo S & Rogan J & Uys JM \\
\hline Ala J & De Villiers L & Hayes VM & Luiz DM & Naidoo Z & Rogerson CM & Van der Merwe A \\
\hline Alpaslan $\mathrm{AH}$ & De Wet G & Hemson C & Macphail AP & Nair $\mathrm{CH}$ & Roos SD & Van der Meyden $\mathrm{CH}$ \\
\hline Baloyi LI & Dicker A & Hess SB & Madhi SA & Naong MN & Roos V & Van der Wal D \\
\hline Barker R & Dickinson D & Hewlett L & Makgatle PB & Narismulu GP & Ross $\mathrm{E}$ & Van Heerden PR \\
\hline Barnes J & Du Plessi E & Hoberg SM & Makhunga NV & Nealer EJ & Ross $M$ & Van Niekerk PJM \\
\hline Basson NJ & Du Plessis IMM & Hochfeld T & Makunga NV & Neku RIN & Sadie $Y$ & Van Niekerk R \\
\hline Basson PJ & Du Toit CM & Hofmeyr GJ & Marcus T & Nieman GH & Saffer DS & Van Rooyen L \\
\hline Becker RW & Du Toit M & Hugol & Mare PG & Niewoudt JM & Saloojee H & Van Rooyen RM \\
\hline Bell FR & Dube MW & Human SP & Maree JG & Nikodem VC & Schurink WJ & Van Schalkwyk A \\
\hline Bennett JA & Durrheim M & Iccharam M & Marx GL & Ntusi T & Seoighi C & Van Schalkwyk FE \\
\hline Berry S & Eales CJ & Ingram C & Matheniwa LF & Nyembe BT & Shai-Mahoko NS & Van Wyk JN \\
\hline Beukes S & Ebersohn L & Isaacs DM & May J & Ogunbanjo GA & Sichone OB & Van Zyl AW \\
\hline Beukes S & Edwards SD & Jackson A & Mbombo NM & Olivier DF & Singh $R$ & Venter CS \\
\hline Bisschoff CA & Elkonin DS & Janse Rensburg E & Mclnerney PA & Oosthuizen C & Smit BW & Vergnani $T$ \\
\hline Bloem CHM & Erasmus BJ & Janse van Rensburg J & McIntyre DE & Oosthuizen W & Smith MS & Viedge C \\
\hline Bolton KD & Esterhuizen $\mathrm{HL}$ & Jansen ZL & Mclntyre JA & Patel M & Smith S & Von Kotze AELV \\
\hline Booyens B & Evian C & Joubert JMJ & McKendrick BW & Peltzer & Snyders FJA & Vos L \\
\hline Bornman A & Fatti LP & Joubert KD & McKenzie A & Petersen NF & Soderlund RN & Waldman PL \\
\hline Bornstein L & Finlayson R & Kahn K & McLennan AC & Pettipher OR & Solomon V & Walker $\mathrm{E}$ \\
\hline Collins A & Glencross DK & Kok JC & Meyer D & Philippe X & Solomon VP & Wallmach AK \\
\hline Cornwell L & Gow J & Kotze GJ & Moola MH & Pillay J & Sookrajh R & Wassenaar DR \\
\hline Cronje JC & Graham-Jolly M & Kotze HF & Mouton J & Reekie WD & Squelch JM & Watson SFT \\
\hline Crous SFM & Gravett SJ & Kruger L-M & Mugambi JNK & Reynolds PF & Thsiwula JL & Weeks FH \\
\hline De Beer SF & Grobbelaar J & Kruger $P$ & Muller JC & Ribbens IR & Tiemessen CT & \\
\hline de Gruchy SM & Groenewald MM & Kunene PI & Muller ME & Richter LM & Todes AE & \\
\hline De Klerk BJ & Gumbi TAP & Lesch $\mathrm{E}$ & Mwaba K & Ridder JH & Trigaardt JD & \\
\hline
\end{tabular}

